\title{
TSPYL2 wt Allele
}

National Cancer Institute

\section{Source}

National Cancer Institute. TSPYL2 wt Allele. NCI Thesaurus. Code C101298.

Human TSPYL2 wild-type allele is located in the vicinity of Xp11.2 and is approximately 6 $\mathrm{kb}$ in length. This allele, which encodes testis-specific Y-encoded-like protein 2, plays a role in the remodeling of chromatin. 